OPEN ACCESS

Edited by: Morten Lillemo, Norwegian University of Life Sciences, Norway

Reviewed by: Zhaohui Liu, North Dakota State University, United States Graham Robert David McGrann, Science and Advice for Scottish Agriculture (SASA), United Kingdom

*Correspondence:

Reem Aboukhaddour reem.aboukhaddour@canada.ca

Specialty section: This article was submitted to Plant Microbe Interactions, a section of the journal

Frontiers in Plant Science

Received: 10 September 2019 Accepted: 07 November 2019

Published: 18 December 2019

Citation:

Kamel S, Cherif M, Hafez M, Despins $T$ and Aboukhaddour $R$ (2019) Pyrenophora tritici-repentis in Tunisia: Race Structure and Effector Genes.

Front. Plant Sci. 10:1562. doi: 10.3389/fp/s.2019.01562

\section{Pyrenophora tritici-repentis in Tunisia: Race Structure and Effector Genes}

\author{
Sana Kamel ${ }^{1}$, Mejda Cherif ${ }^{1}$, Mohamed Hafez ${ }^{2}$, Therese Despins ${ }^{2}$ and \\ Reem Aboukhaddour ${ }^{2 *}$ \\ ${ }^{1}$ Laboratory of Genetics and Cereal Breeding, Department of Agronomy and Plant Biotechnology, National Agronomic \\ Institute of Tunisia, University of Carthage, Tunis, Tunisia, ${ }^{2}$ Cereal Pathology Lab, Agriculture and Agri-Food Canada, \\ Lethbridge Research and Development Centre, Lethbridge, AB, Canada
}

Tan spot is a destructive foliar wheat disease worldwide and caused by the ascomycete fungus Pyrenophora tritici-repentis (Ptr); it has become more frequent in Tunisia over the last decade. In this study, the virulence of 73 single-spore isolates, collected from durum and bread wheat fields during 2017-2018 growing season, was evaluated on four differential wheat genotypes. This was followed by polymerase chain reaction tests with specific primers for the effector genes ToxA, ToxB, and toxb (ToxB-homolog). Sequence analysis to validate the identity of the amplified genes was followed, and ToxA amplicons from a subset of 22 isolates were analyzed to determine its haplotype identity. Ptr isolates from Tunisia were grouped in races 2, 4, 5, and 7, and 44\% of the tested isolates did not fit under any known race, and were denoted here as atypical. These atypical isolates induced the same symptoms as race 7 isolates, extensive necrosis, and chlorosis on susceptible genotypes, but lacked the ToxA gene. ToxA is the only identified necrosisinducing effector in Ptr, and was amplified in 51\% of tested isolates, and shared identical sequence to previously identified haplotype $(\mathrm{H} 15)$. ToxB and its homolog toxb were present in 97\% and 93\% of tested isolates, respectively. Ptr in Tunisia lacked Ptr ToxC activity, and none of the tested isolates induced the specific symptoms of that effector. Race 7 and the atypical isolates dominated the Tunisian Ptr population, while races 2, 4, and 5 were found at low percentages. In conclusion, ToxB and its homolog were the most dominant genes in Ptr from Tunisia, and the majority of the isolates induced necrosis and chlorosis on Ptr ToxA and Ptr ToxB susceptible wheat genotypes. However, only about half of that necrosis can be attributed to ToxA presence, this result necessitates further research to investigate the prevalence of additional necrotic effector(s).

Terminology: in this paper, Pyrenophora tritici-repentis abbreviated as Ptr, the effectors are referred to by Ptr ToxA, Ptr ToxB and Ptr ToxC, and the genes coding for them are written in italic as ToxA, ToxB, and ToxC, respectively. 


\section{INTRODUCTION}

Tan spot of wheat is an important foliar disease found in major wheat-growing regions throughout the world. The causing pathogen is the ascomycete fungus Pyrenophora tritici-repentis (Died) (anamorph Drechslera tritici-repentis, Died) (Ptr), a necrotroph that infects both bread (Triticum aestivum) and durum wheat (T. turgidum). Tan spot is a disease of relatively recent history; it emerged as a threat to wheat over the last 40 years (Friesen et al., 2006). The wide adoption of minimum tillage practices and widespread cultivation of Tsn1-carrying wheat have likely caused a spike in its incidence and severity throughout the world (Lamari et al., 2005a). Beside its wheat host, Ptr was isolated from several grass species (Krupinsky, 1982; Ali and Francl, 2003), but it is known to cause severe damage only to wheat, although moderate symptoms were observed on other gramineous hosts (Morrall and Howard, 1975; Krupinsky, 1982; Summerell and Burgess, 1988). Lately, a specific interaction between Ptr and barley was evident, and confirmed the ability of Ptr effectors to interact specifically with additional hosts beside wheat (Aboukhaddour and Strelkov, 2016; See et al., 2019).

Tan spot is a stubble-born disease and the causing fungus overwinters as pseudothecia on wheat residue. Early in the growing season, infection by ascospores and conidia occur. When the spores land on susceptible wheat leaf under conducive conditions of continuous wetness and cool temperature, the spores germinate and penetrate through the epidermal cells or the stomata to invade the epidermal layer where the hypha grow intracellularly (inside cells). Then the fungus will invade the mesophyll layer intercellularly (between cells) causing damage to the organelle beyond its advancing hypha as results of necrotrophic effectors secretion by the pathogen (De Wolf et al., 1998; Aboukhaddour et al., 2011). Soon after the conidia germinate it secretes its necrotrophic effectors, previously known as host-selective toxins, that kill the plant cells so the fungus can acquire its nutrients from the dead cells. The infection manifests itself as tan colored necrotic or chlorotic lesions depending on the effector produced by the pathogen and the susceptibility gene in the host.

Ptr follows the inverse gene-for-gene interaction with its wheat host. In that, the unique interaction is genetically mediated between a dominant virulence from the pathogen side and a dominant susceptibility from the host side (Lamari and Strelkov, 2010). Ptr produces several necrotrophic effectors, three are identified as Ptr ToxA, Ptr ToxB, and Ptr ToxC. The Ptr ToxA protein is the only identified necrosis inducing effector in Ptr, and was the first proteinaceous necrotrophic effector reported in a fungal species (Ballance et al., 1996). It is encoded by a single copy gene, the ToxA gene (Ballance et al., 1996; Ciuffetti et al., 1997). On the other hand, Ptr ToxB and Ptr ToxC each induces chlorosis but on different wheat genotypes carrying different susceptibility genes to these two effectors. Ptr ToxB is the second proteinaceous effector identified in Ptr, and is encoded by a multi-copy gene, the ToxB gene (Strelkov et al., 1999; Martinez et al., 2001). Ptr ToxC exact nature and its coding gene (s) has not precisely identified, and an earlier research suggested that
Ptr ToxC is a low-molecular-mass molecule (Effertz et al., 2002). Both ToxA and ToxB have homolog sequences in other related fungal species. ToxA identical sequence with $99.7 \%$ match was found in the wheat pathogen, Stagonospora nodorum (Friesen et al., 2006), and homolog of this gene was identified in the maize pathogen Cochliobolus heterostrophus (Lu et al., 2015) and in Bipolaris sorokiniana, which infect both wheat and barley (Stukenbrock and McDonald, 2007; McDonald et al., 2018). Yet in the same Ptr species, there are no homologs of this gene in isolates lacking the ability to produce the Ptr ToxA effector, and only the producing isolates carry the single copy ToxA gene (Aboukhaddour et al., 2009). On the other hand, homologs of ToxB were found in other fungal species of Cochliobolus, Alteranaria, and Pyrenophora (Andrie et al., 2008; Andrie and Ciuffetti, 2011), and in the Ptr isolates that do not produce the active $\operatorname{Ptr}$ ToxB protein.

Based on the pathogen ability to secrete combinations of these three effectors, eight different races have been identified worldwide and designated as race 1 through 8 (Lamari et al., 2003). Races 2, 3, and 5 produces one effector each Ptr ToxA, Ptr ToxC, and Ptr ToxB, respectively. Races 1, 6, and 7 produces combination of two effectors each, (Ptr ToxA + Ptr ToxC), (Ptr ToxB + Ptr ToxC), and (Ptr ToxA + Ptr ToxB), respectively. Race 8 is the most complex and produces the three effectors, while race 4 is the non-pathogenic and incapable of producing any of these effectors.

Research over the last 30 years in Canada, USA, South America, and Australia showed that Ptr ToxA-producing isolates of races 1 and 2 are the most predominant in these regions (Lamari et al., 1998; Ali and Francl, 2003; Friesen et al., 2005; Lamari et al., 2005b; Engle et al., 2006; Singh et al., 2007; Ali et al., 2010; Antoni et al., 2010; LeisovaSvobodova et al., 2010; Lepoint et al., 2010; Gamba et al., 2012; Aboukhaddour et al., 2013; Abdullah et al., 2017a; MacLean et al., 2017). On the other hand, Ptr ToxB-producing isolates have not been reported in Australia and New Zealand (Antoni et al., 2010; Weith, 2015), and were rarely found in the Americas (Aboukhaddour et al., 2013). Yet, Ptr race structure in regions encompassing the wheat center of origin, where wheat cultivations goes back thousands of years, like in the Middle East, North Africa, and the Caucasus regions, a high complexity in Ptr virulence is present, with all the eight races and effectors found and more likely to be identified (Lamari et al., 2005b; Aboukhaddour et al., 2009).

In North Africa, Ptr race structure was previously investigated in both Algeria and Morocco, and while Ptr ToxA-producing isolates dominated the Algerian fields as found by Benslimane et al. (2011), races 5 and 6 that lack the ability to produce Ptr ToxA, were the only detected races in Algeria in previous survey in 1993 (Lamari et al., 1995; Strelkov et al., 2002). In Morocco, races 5 and 6, Ptr ToxB-producers, composed the majority of Ptr isolates (Gamba et al., 2017). This study aims at investigating the Ptr race composition in Tunisia, an important wheat growing region in North Africa, to get more understanding of Ptr virulence in this area. The ToxA gene sequences from Ptr Tunisian isolates was analyzed in this study and compared to already published sequences from different parts of the world. 


\section{MATERIALS AND METHODS}

\section{Fungal Isolates}

A survey of bread and durum wheat crops in Northern Tunisia, where wheat is growing, was conducted in 2017-2018 growing season to evaluate leaf spot incidence and severity. Leaf samples with typical tan spot symptoms were collected from individual wheat fields in the eight major wheat-growing areas. In total, 45 fields were surveyed in two different climatic regions, subhumid (Bizerte, Beja) and semi-arid region of northern Tunisia (Tunis, Ariana, Manouba, Jendouba, Siliana and El Kef) (Table 1, Figure 1).

Leaves with visible lesions were cut into $2 \mathrm{~cm}$ long segments. These segments were then surfaces-sterilized in $1 \%$ sodium hypochlorite solution for $2 \mathrm{~min}$ followed by water rinse twice for $30 \mathrm{~s}$ in sterile distilled water, and were placed in Petri plates containing moistened Whatman ${ }^{\circ}$ No. 1 filter paper (Whatman International Ltd., Maidstone, UK). The plates were incubated for $24 \mathrm{~h}$ at room temperature under fluorescent light, then transferred to the dark and incubated for additional $24 \mathrm{~h}$ at $15^{\circ} \mathrm{C}$ in the dark. The segments were then exanimated under stereoscope and single conidia were transferred each to individual 9-cm diameter Petri plates filled with V8-potato dextrose agar (V8-PDA) (Lamari and Bernier, 1989a). Single spore cultures were used to generate inoculum as described below.

\section{Inoculum Preparation and Bioassays}

Inoculum preparation was done as previously described (Lamari and Bernier, 1989a; Lamari and Bernier, 1989b), the Ptr culture were grown in darkness at room temperature for a week, then mycelial plugs $(0.5 \mathrm{~cm}$ in diameter) were excised from the growing cultures and transferred individually into a 9-cm Petri plates filled with V8-PDA and were incubated for 5 days in the dark at room temperature or until the colonies were $4 \mathrm{~cm}$ in diameter. Sterile distilled water was added to each colony and the mycelium were flattened with the bottom of flamed sterilized glass tube and excess water was decanted. The plates were then placed under fluorescent light for $18 \mathrm{~h}$ at room temperature, followed by $24 \mathrm{~h}$ incubation period at $15^{\circ} \mathrm{C}$ in the dark. Conidia were harvested after flooding the cultures with sterile distilled water and dislodging the spores gently with a wire loop. The inoculum concentration was adjusted to 3000 conidia $\mathrm{ml}^{-1}$ using a Fuchs Rosenthal Counting Chamber (Hausser Scientific, Blue Bell, PA). One drop of Tween 20 (polyoxyethylene sorbitan monolaurate) was added per $100 \mathrm{ml}$ of conidia suspension.

\section{Wheat Differential and Symptoms Rating}

A differential set composed of four hexaploid wheat genotypes ("Glenlea," 6B662, 6B365, and "Salamouni") were used in this study. These four genotypes can differentiate between the known eight races of the pathogen. Seeds of each genotypes were sown in 10-cm-diameter plastic pots filled with Sunshine potting Mix (W.R. Grace and Co., Fogelsville, PA) at a rate of eight seeds by pot. One genotype was seeded per pot, and all treatments were replicated twice, and the whole bioassay was repeated one
TABLE 1 | Isolate code, geographic origin, host, $\mathrm{PCR}$ reaction, and race of $\mathrm{Ptr}$ isolates collected from different locations of Tunisia, and analyzed in this study.

\begin{tabular}{|c|c|c|c|c|c|c|}
\hline \multirow[t]{2}{*}{ Isolate $^{*}$} & \multirow[t]{2}{*}{ Province } & \multirow[t]{2}{*}{ Host } & \multicolumn{3}{|c|}{ PCR reaction } & \multirow[t]{2}{*}{ Race } \\
\hline & & & ToxA & ToxB & toxb & \\
\hline T126-1 & Ariana & DW & - & - & - & $\mathrm{R} 4$ \\
\hline T128-1 & Ariana & DW & - & + & + & Atypical \\
\hline T132-2 & Beja & DW & + & - & - & $\mathrm{R} 2$ \\
\hline T133-3-4 & Beja & DW & - & + & + & Atypical \\
\hline T174-1 & Beja & BW & - & + & + & Atypical \\
\hline T177-1 & Beja & BW & - & + & + & Atypical \\
\hline T177-3 & Beja & BW & - & + & + & Atypical \\
\hline T177-4 & Beja & BW & - & + & + & Atypical \\
\hline T178-3 & Beja & BW & - & + & + & Atypical \\
\hline T172-2 & Beja & DW & + & + & + & $\mathrm{R} 7$ \\
\hline T130-2 & Beja & DW & + & + & + & $\mathrm{R} 7$ \\
\hline T130-4 & Beja & DW & + & + & + & $\mathrm{R} 7$ \\
\hline T135-1 & Beja & DW & + & + & + & $\mathrm{R} 7$ \\
\hline T173-4 & Beja & DW & - & + & + & Atypical \\
\hline T173-5 & Beja & DW & + & + & + & $\mathrm{R} 7$ \\
\hline T173-9 & Beja & DW & + & + & + & $\mathrm{R} 7$ \\
\hline T176-1 & Beja & BW & + & + & + & $\mathrm{R} 7$ \\
\hline T176-2 & Beja & BW & + & + & - & $\mathrm{R} 7$ \\
\hline T176-3 & Beja & BW & + & + & + & $\mathrm{R} 7$ \\
\hline T178-1 & Beja & BW & + & + & + & $\mathrm{R} 7$ \\
\hline T178-2 & Beja & BW & + & + & + & $\mathrm{R} 7$ \\
\hline T179-1 & Beja & BW & + & + & + & $\mathrm{R} 7$ \\
\hline T179-2 & Beja & BW & + & + & + & $\mathrm{R} 7$ \\
\hline TB1-1 & Beja & DW & + & + & + & $\mathrm{R} 7$ \\
\hline TB1-2 & Beja & DW & + & + & + & $\mathrm{R} 7$ \\
\hline T165-1 & Bizerte & DW & - & + & + & Atypical \\
\hline T165-2 & Bizerte & DW & - & + & + & Atypical \\
\hline T167-0 & Bizerte & DW & - & + & + & Atypical \\
\hline T20-1 & Bizerte & DW & - & + & + & Atypical \\
\hline T20-2 & Bizerte & DW & - & + & + & Atypical \\
\hline T169 & Bizerte & DW & + & + & + & $\mathrm{R} 7$ \\
\hline T17-2 & Bizerte & DW & + & + & + & $\mathrm{R} 7$ \\
\hline T25-4 & Bizerte & DW & + & + & + & $\mathrm{R} 7$ \\
\hline Т25-7 & Bizerte & DW & + & + & + & $\mathrm{R} 7$ \\
\hline T44-1 & Bizerte & DW & + & + & + & $\mathrm{R} 7$ \\
\hline T44-4 & Bizerte & DW & + & + & + & $\mathrm{R} 7$ \\
\hline T143-6 & Jendouba & DW & - & + & + & Atypical \\
\hline T143-7 & Jendouba & DW & - & + & + & R5 \\
\hline T152-2 & Jendouba & DW & - & + & + & Atypical \\
\hline T61-19 & Jendouba & DW & - & + & + & Atypical \\
\hline T6-2-1 & Jendouba & DW & - & + & + & Atypical \\
\hline T64-39 & Jendouba & DW & - & + & + & R5 \\
\hline T65-44 & Jendouba & DW & - & + & + & Atypical \\
\hline T70-66 & Jendouba & DW & - & + & + & Atypical \\
\hline TE6-6.2B & Jendouba & DW & - & + & + & Atypical \\
\hline TE6-6.6B & Jendouba & DW & - & + & + & Atypical \\
\hline TJ2-1 & Jendouba & DW & - & + & + & Atypical \\
\hline T146-5 & Jendouba & DW & + & + & + & $\mathrm{R} 7$ \\
\hline T181-1 & Jendouba & DW & + & + & + & $\mathrm{R} 7$ \\
\hline T2-1-6 & Jendouba & DW & + & + & + & $\mathrm{R} 7$ \\
\hline Т2-5-2 & Jendouba & DW & + & + & + & $\mathrm{R} 7$ \\
\hline T75-1 & Jendouba & DW & + & + & + & $\mathrm{R} 7$ \\
\hline TPTR3-1 & Jendouba & DW & + & + & + & $\mathrm{R} 7$ \\
\hline T62-28-4 & Jendouba & DW & + & + & + & $\mathrm{R} 7$ \\
\hline T157-2 & El Kef & DW & - & + & - & Atypical \\
\hline T157-3 & El Kef & DW & - & + & + & Atypical \\
\hline T157-5 & El Kef & DW & - & + & + & Atypical \\
\hline T102-1 & Manouba & DW & - & + & + & Atypical \\
\hline Т39-3 & Manouba & DW & - & + & + & Atypical \\
\hline T39-5 & Manouba & DW & - & + & + & Atypical \\
\hline
\end{tabular}

(Continued) 
TABLE 1 | Continued

\begin{tabular}{|c|c|c|c|c|c|c|}
\hline \multirow[t]{2}{*}{ Isolate $^{*}$} & \multirow[t]{2}{*}{ Province } & \multirow[t]{2}{*}{ Host } & \multicolumn{3}{|c|}{ PCR reaction } & \multirow[t]{2}{*}{ Race } \\
\hline & & & ToxA & ToxB & toxb & \\
\hline T103-1 & Manouba & DW & + & + & + & $\mathrm{R} 7$ \\
\hline T103-2 & Manouba & DW & + & + & + & $\mathrm{R} 7$ \\
\hline TPtr 47-3 & Siliana & DW & - & + & + & Atypical \\
\hline TPtr 47-4 & Siliana & DW & - & + & + & Atypical \\
\hline T171-1 & Tunis & DW & - & + & + & R5 \\
\hline T129-4 & Tunis & DW & - & + & + & Atypical \\
\hline T129-5 & Tunis & DW & - & + & + & Atypical \\
\hline T168-1 & Tunis & DW & + & + & + & $\mathrm{R} 7$ \\
\hline T168-2 & Tunis & DW & + & + & + & $\mathrm{R} 7$ \\
\hline T168-3 & Tunis & DW & + & + & + & $\mathrm{R} 7$ \\
\hline T168-4 & Tunis & DW & + & + & + & $\mathrm{R} 7$ \\
\hline T168-6 & Tunis & DW & + & + & + & $\mathrm{R} 7$ \\
\hline T168-7 & Tunis & DW & + & + & - & $\mathrm{R} 7$ \\
\hline
\end{tabular}

*Isolates designation: $T$ for Tunis, the number after the $T$, indicates the number of field from which isolates was collected, and the number after the dash line is denoted for the particular isolates included in this study.

$D W$, durum wheat; $B W$, bread wheat.

+ , amplification of the toxin gene; -, no amplification of the toxin gene.

additional time. Pots were placed in a growth chamber at $16 \mathrm{~h}$ photoperiod $\left(22^{\circ} \mathrm{C}\right.$ day $/ 18^{\circ} \mathrm{C}$ night $)$ at $180 \mathrm{mmol} \mathrm{m}{ }^{-2} \mathrm{~s}^{-1}$, for seed germination and seedling development. After 14 days, and when plants reached the two leaf stage, seedlings were inoculated and rated for symptoms development 6 days after inoculation. Wheat seedlings were sprayed with the conidial suspension [3000 conidia $\mathrm{ml}^{-1}$ and one drop of Tween 20 (polyoxyethylene sorbitan monolaurate) $100 \mathrm{ml}^{-1}$ ] until runoff using a sprayer connected to an airline.

Immediately following inoculation, the seedlings were covered with plastic bag to maintain humidity. The seedlings were then transferred to a growth cabinet and kept at $20^{\circ} \mathrm{C} / 18^{\circ} \mathrm{C}$ (day/night) with a $16 \mathrm{~h}$ photoperiod $\left(180 \mathrm{mmol} \mathrm{m}^{-2} \mathrm{~s}^{-1}\right)$. The three isolates Asc1 (race 1), D308 (race 3), and Alg3-24 (race 5), Ptr ToxA, Ptr ToxC, and Ptr ToxB-producers, respectively, were used in each inoculation as positive control for the symptoms corresponding to each effector.

\section{Genomic DNA Extraction}

Genomic DNA (gDNA) was extracted using $40 \mathrm{mg}$ of lyophilized mycelium. In order to produce mycelia, $3 \mathrm{ml}$ of spore suspension $\sim 3000$ conidia $\mathrm{ml}^{-1}$ were transferred to $250 \mathrm{ml}$ Erlenmeyer flasks containing $100 \mathrm{ml}$ of Fries liquid medium $\left[5 \mathrm{~g}(\mathrm{NH})_{4} \mathrm{C}_{4} \mathrm{H}_{4} \mathrm{O}_{6}, 1\right.$ $\mathrm{g} \mathrm{NH}_{4} \mathrm{NO}_{3}, 0.5 \mathrm{~g} \mathrm{MgSO}_{4} .7 \mathrm{H}_{2} \mathrm{O}, 0.13 \mathrm{~g} \mathrm{KH}_{2} \mathrm{PO}_{4}, 0.26 \mathrm{~g} \mathrm{~K}_{2} \mathrm{HPO}_{4}$, $30 \mathrm{~g}$ sucrose, $1 \mathrm{~g}$ yeast extract, $2 \mathrm{ml}$ trace element stock solution] (Dhingra and Sinclair, 1986). Flasks were incubated in darkness at $20^{\circ} \mathrm{C}$ for 3 weeks. The mycelial mats were separated from the liquid medium by vacuum filtration through Whatman ${ }^{\circledR}$ No. 1 filter paper. Mycelia mats were then flash-frozen in dry ice and lyophilized in a freeze-drier prior to DNA extraction.

The gDNA was extracted from each isolate using the Wizard ${ }^{\circledR}$ Genomic DNA Extraction Kit (Promega Corporation, Madison, WI), according to the manufacturer's protocol for plant material, with added steps one with phenol chloroform $(1: 1 \mathrm{v} / \mathrm{v})$ followed by one extraction with chloroform. The DNA quantity and quality was measured using a NanoDrop ND-1000 spectrophotometer (Thermo Scientific, Wilmington, DE), and adjusted to a final concentration of $50 \mathrm{ng} \mathrm{\mu l}^{-1}$ in Tris-EDTA buffer.

\section{PCR Amplification of Effector Genes}

Singleplex PCR analysis to detect the presence or absence of the effectors genes ToxA and ToxB and its homolog toxb in Ptr population in Tunisia was performed using gDNA from the 73 Ptr isolates tested in this study. Two ToxA-specific primer pairs were used to detect the presence or absence of ToxA gene (Table 2), one pair targeting the ToxA-ORF (ToxA1/ToxA2) and a second pair targeting a larger fragment contains ToxA-ORF

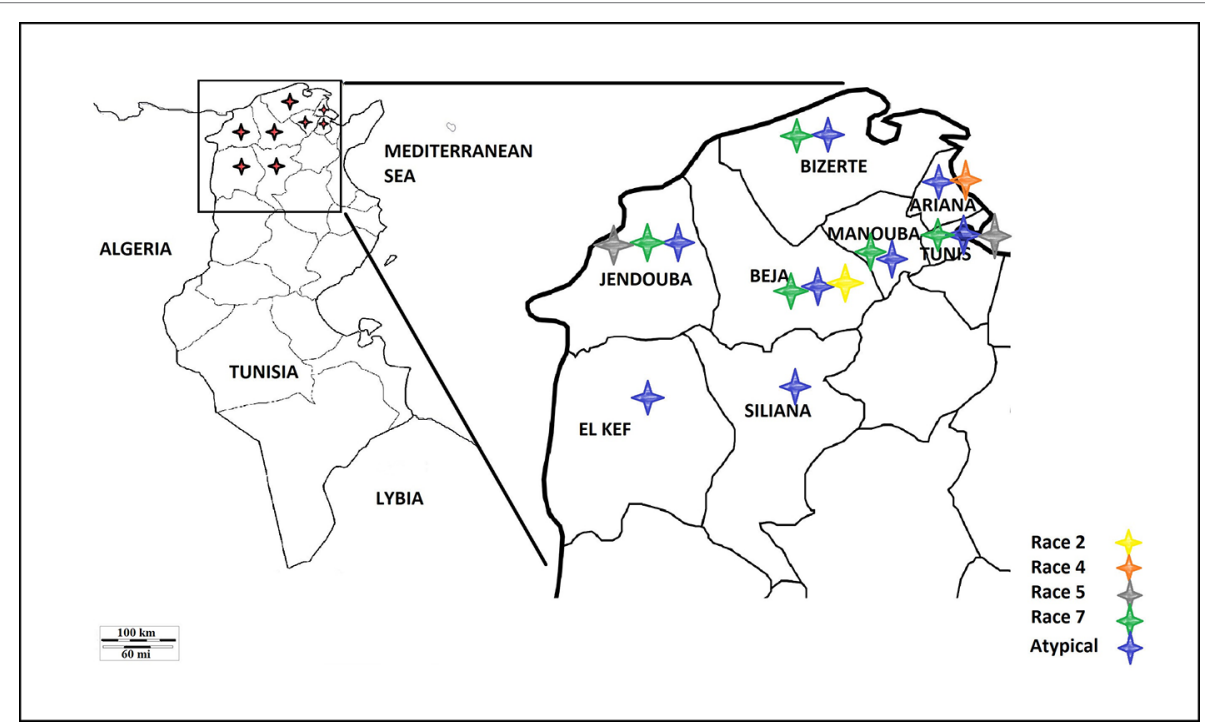

FIGURE 1 | Map of Tunisia and the different Ptr races identified. 
TABLE 2 | Primers used for amplification of the TOXA, TOXB and toxb genes in Ptr isolates.

\begin{tabular}{|c|c|c|c|}
\hline Gene & $\begin{array}{l}\text { Primer for } \\
\text { singleplex } \\
\text { PCR }\end{array}$ & Sequence & $\begin{array}{l}\text { Estimated } \\
\text { band size } \\
\text { (bp) }\end{array}$ \\
\hline \multirow[t]{2}{*}{ TOXA } & TOXA192 & 5'-CGT CCG GCT ACC TAG CAA TA-3' & 964 \\
\hline & TOXA1155 & 5'-TTG TGC TCC TCC TTC TCG AT-3' & \\
\hline \multirow[t]{2}{*}{ TOXA } & ToxA1 & 5'-GTC ATG CGT TCT ATC CTC G-3' & \\
\hline & ToxA2 & 5'-CCT ATA GCA CCA GGT CGT CC-3' & 294 \\
\hline \multirow[t]{2}{*}{ ToxB } & ToxB1 & 5'-GAC TAC CAT GCT ACT TGC TGT G-3' & \\
\hline & ToxB2 & 5'-AAC AAC GTC CTC CAC TाT GC-3' & 245 \\
\hline \multirow[t]{2}{*}{ toxb } & $90-2 F 1$ & 5'-AAG TGG TCA TTG CGA CTG G-3' & \\
\hline & $90-2 R 1$ & 5'-CCT CCA CTT GCC AAA CTC TC-3' & 157 \\
\hline Gene & $\begin{array}{l}\text { Primer for } \\
\text { multiplex } \\
\text { PCR }\end{array}$ & Sequence & $\begin{array}{l}\text { Estimated } \\
\text { band size } \\
\text { (bp) }\end{array}$ \\
\hline $\mathrm{CHS}-1$ & $\begin{array}{l}\text { CHS-79F } \\
\text { CHS-354R }\end{array}$ & $\begin{array}{l}\text { 5'-TGGGGCAAGGATGCTTGGAAGAAG-3' } \\
\text { 5'-TGGAAGAACCATCTGTGAGAGTTG-3' }\end{array}$ & 275 \\
\hline TOXA & $\begin{array}{l}\text { TA51F } \\
\text { TA52R }\end{array}$ & $\begin{array}{l}\text { 5'-GCGTTCTATCCTCGTACTTC-3' } \\
\text { 5'-GCATTCTCCAATITCACG-3 }\end{array}$ & 573 \\
\hline ToxB & $\begin{array}{l}\text { TB71F } \\
\text { TB60R }\end{array}$ & $\begin{array}{l}\text { 5'-GCTACTTGCTGTGGCTATC-3 } \\
\text { 5'-ACTAACAACGTCCTCCACTITG-3' }\end{array}$ & 232 \\
\hline toxb & $\begin{array}{l}\text { TB71F } \\
\text { TB58R }\end{array}$ & $\begin{array}{l}\text { 5'-GCTACTTGCTGTGGCTATC-3 } \\
\text { 5'-TATGAATGATTGACTGGGGTTA-3' }\end{array}$ & 232 \\
\hline
\end{tabular}

and non-coding regulatory sequences (ToxA192/ToxA1155). ToxB primers (ToxB1/ToxB2) designed to amplify the ORF of this gene. The primers used for toxb amplification (toxb90-2F1/ toxb90-2R1) were designed with Primer 3 software (Rozen and Skaletsky, 2000) based on sequences of toxb in a Canadian race 4 (GenBank accession No. AF483832.1) (Table 2). To confirm the results obtained by the singleplex PCR, a multiplex PCR was followed on representative Tunisian Ptr isolates of races 2, 4, 5,7 and the atypical isolates. In addition, previously identified and confirmed isolates of races $1,2,3,4$, and 5 were included. In the multiplex PCR, primers specific to the chitin synthase 1 (CHS1) gene, a conserved gene in fungi, were added as a control test for the presence of fungal DNA. In addition, primers specific to ToxA, ToxB, and toxb in the multiplex were all adopted from Andrie et al. (2007) (Table 2).

Singleplex PCR reactions were performed in a final volume of $50 \mu l$ using the Taq PCR core kit (Qiagen Inc. Ontario, Canada) with the following reagent concentrations: CoralLoad PCR buffer (1×); dNTP mixture (200 $\mu \mathrm{M}$ each); forward and reverse primers $(0.2 \mu \mathrm{M}$ each); Taq DNA polymerase $(1.25 \mathrm{U} / 50 \mu \mathrm{l}) ; 50 \mathrm{ng}$ of gDNA template and the total volume of the PCR reaction adjusted to $25 \mu \mathrm{l}$ with nuclease-free $\mathrm{H}_{2} \mathrm{O}$. The amplification conditions consisted of initial denaturation step at $95^{\circ} \mathrm{C}$ for $2 \mathrm{~min}$, followed by 30 cycles of $94^{\circ} \mathrm{C}$ for $50 \mathrm{~s}, 55^{\circ} \mathrm{C}$ for $50 \mathrm{~s}$, and $70^{\circ} \mathrm{C}$ for $50 \mathrm{~s}$ with a final extension at $70^{\circ} \mathrm{C}$ for $7 \mathrm{~min}$. All PCR amplicons (ToxA, ToxB, and toxb) were analyzed by gel electrophoresis through $1.5 \%$ agarose gels in $1 \times$ TBE buffer ( $89 \mathrm{mM}$ Tris-borate, $10 \mathrm{mM}$ EDTA, pH 8.0). The sizes of the PCR amplicons were estimated against a $1 \mathrm{~kb}$ plus ladder (Thermo Fisher Scientific, Canada) and visualized under UV light after staining with RedSafe dye (Intron Biotechnology Inc. Seoul, Korea). PCR amplicons were purified and sequenced by Macrogen (Rockville, MD, USA). Ptr isolates
Asc1 (race 1), 90-2 (race 4), and Alg3-24 (race 5) were used as positive controls for ToxA, tox $b$, and ToxB genes, respectively.

For multiplex PCR, the conditions were adapted from Andrie et al. (2007) with slight modifications. PCR reactions were performed in a final volume of $50 \mu$ using the DreamTaq Green PCR Master Mix (Thermo Fisher Scientific, Canada) with the following reagent concentrations: $1 \times$ Green Taq buffer; $200 \mu \mathrm{M}$ each dNTP; $0.2 \mu \mathrm{M}$ each primer except for TA51F and TA52R primers, $\mu \mathrm{M} 0.4$ from each primer were used; $1.5 \mathrm{U}$ Dream Taq DNA polymerase; 20 ng of gDNA template and the total volume of the PCR reaction adjusted to $50 \mu \mathrm{l}$ with nuclease-free $\mathrm{H}_{2} \mathrm{O}$. PCR amplification included an initial denaturation step at $94^{\circ} \mathrm{C}$ for $3 \mathrm{~min}$, followed by 35 cycles: $94^{\circ} \mathrm{C}$ for $45 \mathrm{~s}, 58^{\circ} \mathrm{C}$ for $30 \mathrm{~s}$, $72^{\circ} \mathrm{C}$ for $1 \mathrm{~min}$, and a final extension at $72^{\circ} \mathrm{C}$ for $10 \mathrm{~min}$.

\section{Sequence Analysis for ToxA, ToxB, and toxb}

ToxA, ToxB, and toxb amplifications were done using primers combination ToxA192/ToxA1155, ToxB1/ToxB2, and 90-2F/90-2R, respectively (Table 2). PCR amplicons were sequenced in both directions with the forward and reverse primers and the generated sequences were compiled and assembled manually into contigs using the GeneDoc program v2.5.010 (Nicholas et al., 1997). The initial nucleotide sequence alignments were done with the Clustal-X program (Thompson et al., 1997) and the resulting alignments were refined by eye with the GeneDoc program.

The consensus ToxA sequence was used to interrogate the online resource Basic Local Alignment Search Tool (BLAST: http://www.ncbi.nlm.nih.gov/BLAST/; Altschul et al., 1990) to retrieve similar sequences from NCBI database to have significant representatives from each ToxA haplotype investigated in the current study. Supplementary Table 1 shows GenBank accession numbers of ToxA, ToxB, and toxb sequences from Tunisian Ptr isolates (MN052875 to MN052896), Canadian Ptr isolates (MN062685 to MN062700), and other sequences retrieved from GenBank for the analysis (EF108451 to EF108463, MH511822, MH511823, and KX816409).

\section{RESULTS}

\section{Race Characterization}

A total of 73 single spore Ptr isolates (61 from durum wheat and 12 from common wheat) were recovered and characterized in this study (Table 1). These isolates were tested for ability to induce symptoms on the differential wheat lines in this study. The majority of the tested isolates $93 \%$ (68) were able to induce necrosis on the wheat differential line "Glenlea" and Chlorosis on $6 \mathrm{~B} 662$, but $6 \mathrm{~B} 365$ and "Salamouni" exhibited a resistant reaction (Figure 2), a symptom typical for race 7.

Three isolates (4\%) were designated as race 5 , since they could induce chlorosis on $6 \mathrm{~B} 662$, but were avirulent on the rest of tested genotypes (Figure 2). Only one isolate (1\%) was classified as race 2, and was able to cause necrosis on "Glenlea" but remain avirulent on the rest of tested genotypes (Figure 2). 


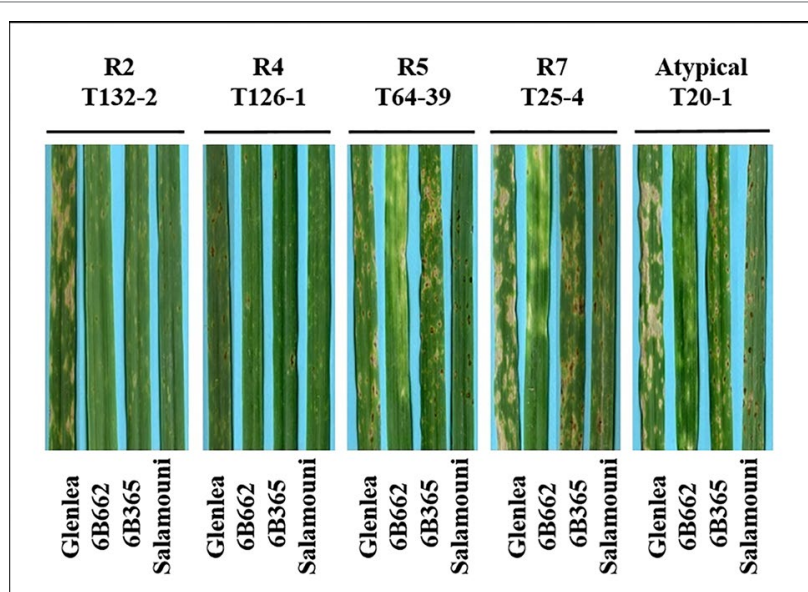

FIGURE 2 | Reaction of differential genotypes to inoculation with representative Ptr isolates collected from Tunisia.

A single isolate (1\%) was classified as race 4, a non-pathogenic, and was avirulent on all tested wheat genotypes (Figure 2). "Salamouni" and 6B365 exhibited resistant reaction to all tested Tunisian isolates (Figure 2). "Salamouni" is known as a resistance genotype for Ptr, and 6B365 is susceptible to Ptr ToxCproducing isolates. In each bioassay, the three isolates ASC1, D308, and Alg3-24 representing races 2, 3, and 5, respectively showed typical symptoms for the race each represents on the differential set.

\section{Presence of ToxA, ToxB, and toxb Genes in Ptr Population in Tunisia}

Singleplex PCR analysis to determine the presence or absence of two effectors genes Tox $A$ and ToxB, and the homolog tox $b$ was done on all the isolates tested above and repeated three independent times. An amplicon corresponding to ToxA gene was present in 51\% (37) of the isolates (Figures 3A, B), and these isolates induced the tan necrosis on "Glenlea." However, this gene was absent in $44 \%$ (32) of the tested isolates (Figures 3A, B), although these 32 isolates caused the typical necrotic symptoms on "Glenlea." This represents an atypical result where the necrosis development on "Glenlea" cannot be attributed to Ptr ToxA presence, and these isolates therefore are designated here as atypical (Table 1). An amplicon corresponding to ToxB was found in $97 \%$ (71) of tested isolates, but was not detected in races 2 and 4 isolates (Figure 3C). As expected, all the isolates that amplified ToxB, induced chlorosis on 6 B662. Its homolog the toxb gene, was also amplified in 93\% (68) of tested isolates and was not detected in isolates of races 2 and 4 (Figure 3D). The multiplex PCR amplification patterns for isolates from races 2, 4, 5,7 , and the atypical were as expected (Figure 3E). CHS-1 gene amplified from all tested isolates (Figure 3E), but ToxA amplicon was detected in isolates of races 2 and 7 , and was absent in isolates from races 5, 4, and the atypical. The ToxB gene amplified from isolates of races 5, 7, and the atypical, but was absent in isolates of races 2 , and 4 as expected (Figure $3 \mathbf{E}$ ).

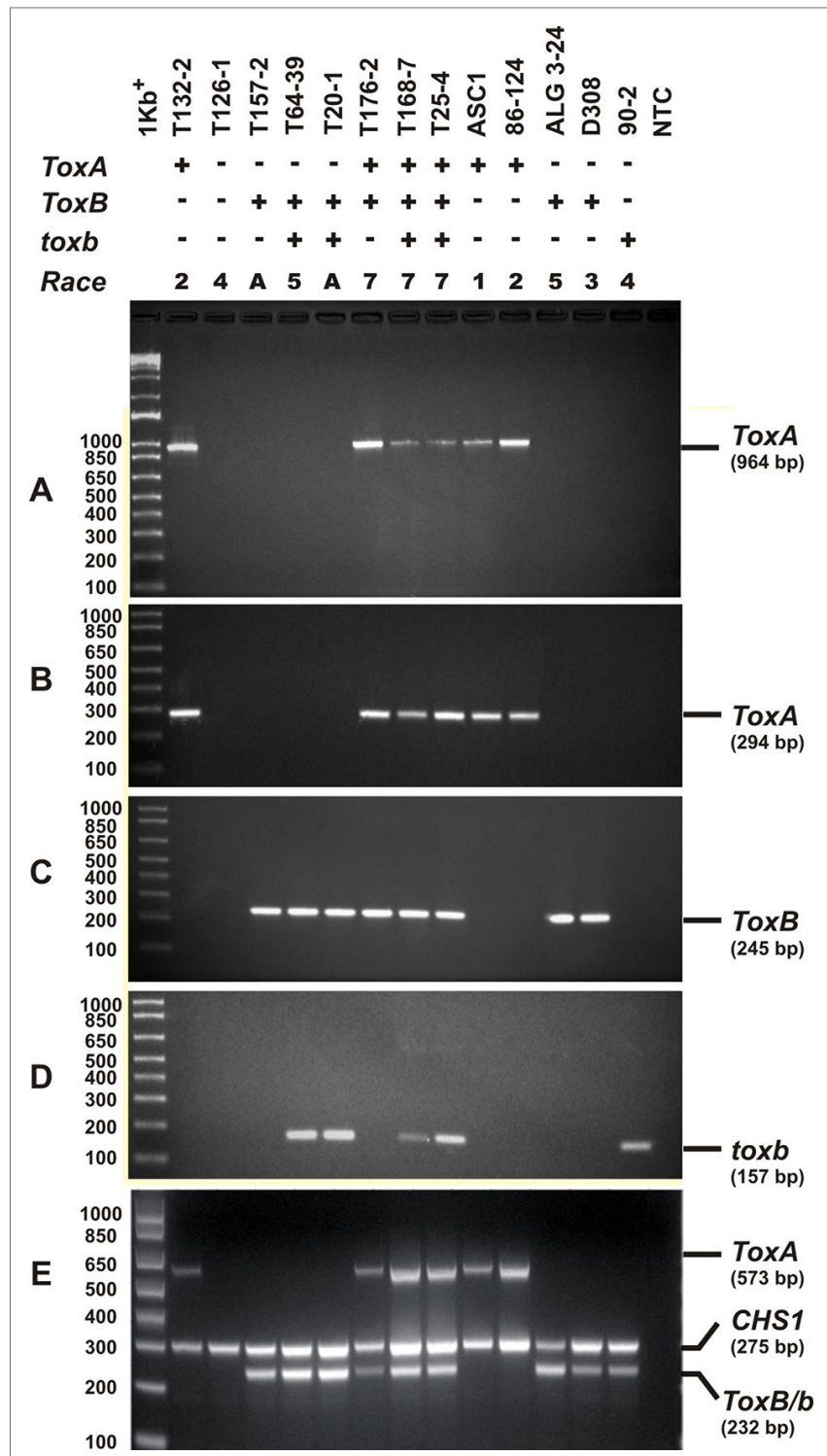

FIGURE 3 | PCR amplification assays with primer sets specific for ToxA, ToxB, and toxb genes. A subset of Ptr isolates used as control, these are ASC1, 86-124, ALG3-24, D308, and 90-2, and they represent races 1, 2, 5, 3, and 4, respectively. Genomic DNA was subjected to PCR analysis with ToxA-specific primers [ToxA192/ToxA1155 (A), ToxA1/ToxA2 (B)], ToxB-specific primers (ToxB1/ToxB2) (C), and toxb-specific primers (90-2F1/90-2R1) (D). A multiplex PCR with specific primers to ToxA, ToxB, toxb, and chitin synthase 1 gene (CHS1) as an internal control for the presence of fungal DNA (E). All PCR products were resolved in 1.5\% agarose supplemented with RedSafe nucleic acids staining solution.

Based on the combined bioassay and PCR results, race 7 is the most predominant in Tunisia, with 36 (49\%) isolates collected from wheat fields in five Tunisian provinces (Tunis, Manouba, Bizerte, Beja, Jendouda) (Table 1). These isolates caused the development of necrosis on the host differential "Glenlea" and chlorosis on 6B662, but were avirulent on 6B365 and "Salamouni" (Figure 2), and amplified both ToxA and ToxB genes (Figures 3A-C, E). The atypical isolates were as dominant, $44 \%$ (32) of the tested isolates, and induced the 
same symptoms on wheat differential as to race 7 , but failed to amplify the ToxA gene (Figures 3A, B, E). These atypical isolates were collected from all surveyed provinces in Tunisia (Figure 1).

Three isolates (4\%) collected from Tunis and Jendouba were designated as race 5 , since they could induce chlorosis on 6B662, and were avirulent on the rest of the tested genotypes (Figure 2), and amplified ToxB but not ToxA (Figures 3A-C, E). A single isolate $(1 \%)$ originated from Beja was classified as race 2 , and was able to cause necrosis on "Glenlea" but remain avirulent on the rest of tested genotypes (Figure 2), and amplified ToxA only (Figures 3A, B, E). A single isolate (1\%) originated from Ariana was classified as race 4 , non-pathogenic, and failed to amplify ToxA or ToxB (Figures $3 \mathrm{~A}-\mathrm{C}$ ).

\section{Sequence Analysis ToxA Haplotypes}

The ToxA-coding region includes two exons consisting of $534 \mathrm{bp}$ separated by one intron of $50 \mathrm{bp}$. All sequenced amplicons in the current study showed identical sequence in both exon and intron regions. Sequence analysis of the Tunisian ToxA and previously published ToxA sequences from Ptr and S. nodurm (Stukenbrock and McDonald, 2007) showed 29 polymorphic sites distributed among 17 different haplotypes (14 haplotype in S. nodorum and 3 haplotypes in Ptr). Three different haplotypes (H14, H15, and H16) were found in ToxA sequences, and the same haplotype (H15) was the only haplotype found in the Tunisian isolates in this current study, and it was also the only ToxA haplotype found in Canadian Ptr isolates (MN062685 to MN062700) collected in 2010 from Alberta. In this study, ToxA sequence analysis reveals a novel haplotype from a $S$. nodorum isolate Fr15-02 that was deposited in GenBank by Australian researchers (GenBank accession MH511823), this potential new in silico identified haplotype $\left(\mathrm{H}^{*}\right)$ is included in Figure 4.

\section{ToxB and Its Homolog toxb}

To $x B$ gene and its homolog to $x b$ from five isolates were sequenced (Table 1). The sequencing results showed that ToxB sequences in these five isolates were identical to ToxB gene in race 5 (Strelkov et al., 2006). In this study, ToxB and toxb sequences were found to be different at three positions at the DNA level similar to what previously reported as race 3 toxb (accession number AF483833) by Strelkov et al. (2006), and these three mutations in toxb gene translated into change in two residues in Ptr ToxB protein at positions 58 and 59. Valine (V58) and glycine (Q59) in the functional Ptr ToxB protein were replaced by Leucine (L58) and Alanine (A59) in the non-functional homolog encoded by tox $b$.

\section{DISCUSSION}

This study aims at determining the race structure of Ptr population in Tunisia, the prevalence of its effector genes, and its ToxA haplotypes. To our knowledge this is the first report of Ptr in Tunisia and ToxA haplotypes in North Africa. Here, a summary of Ptr race structure around the world since 1989 utilizing the race system described by (Lamari et al., 2003) is presented in Figure 5 and Supplementary Table 2. In brief, race 1 of the pathogen is the most predominant race around the world. It is prevalent in the Americas, Europe, North and South Asia, and Russia. However, Ptr population in North Africa and in some regions in the caucuses is unique, with Ptr ToxB-producing

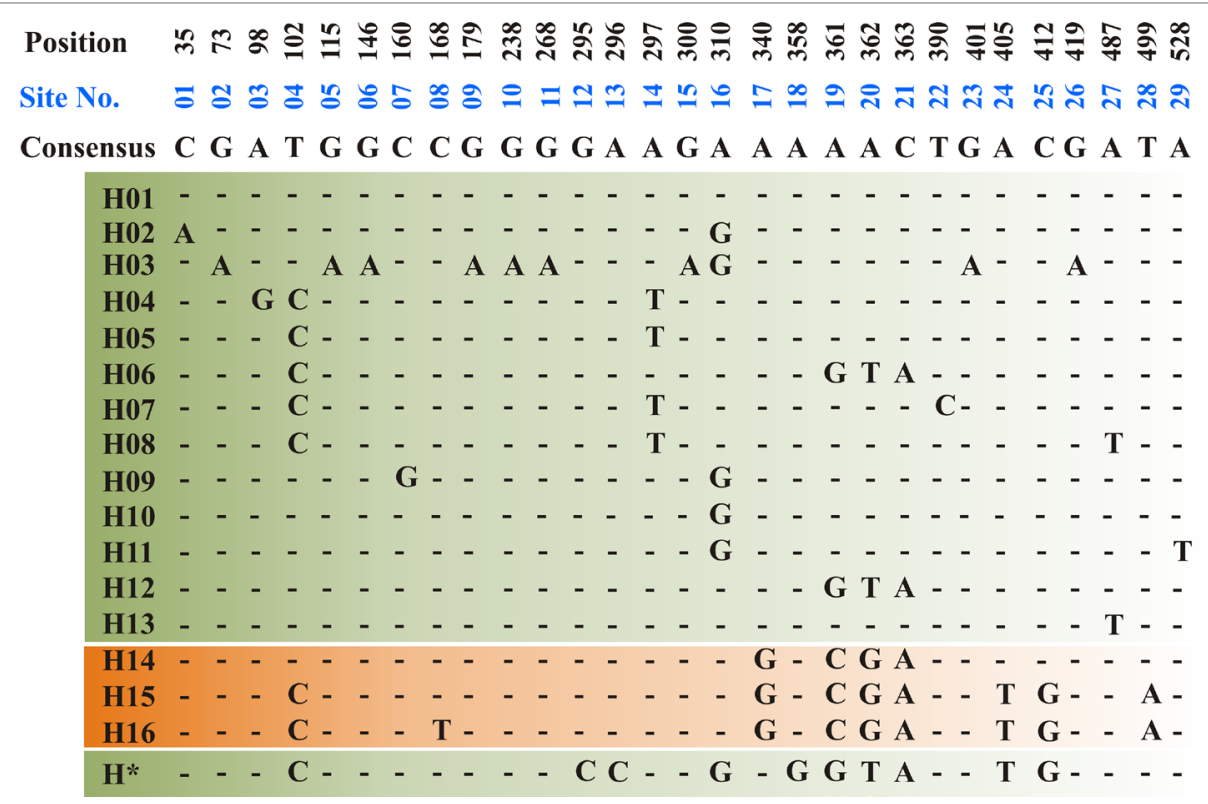

FIGURE 4 | Haplotype alignment for ToxA gene in S. nodorum (H01-H13 - green background) and Ptr (H14-H16-orange background) as cited by Stukenbrock and McDonald, (2007). A potential new S. nodorum haplotype $\left(\mathrm{H}^{*}\right)$ was reported in this study and originated from Australia. A total of 29 polymorphic site $(01-29)$ was recorded and nucleotide positions are numbered relative to ToxA start codon. All Tunisian Ptr isolates investigated during the current study represent the $\mathrm{H} 15 \mathrm{haplotype}$. 


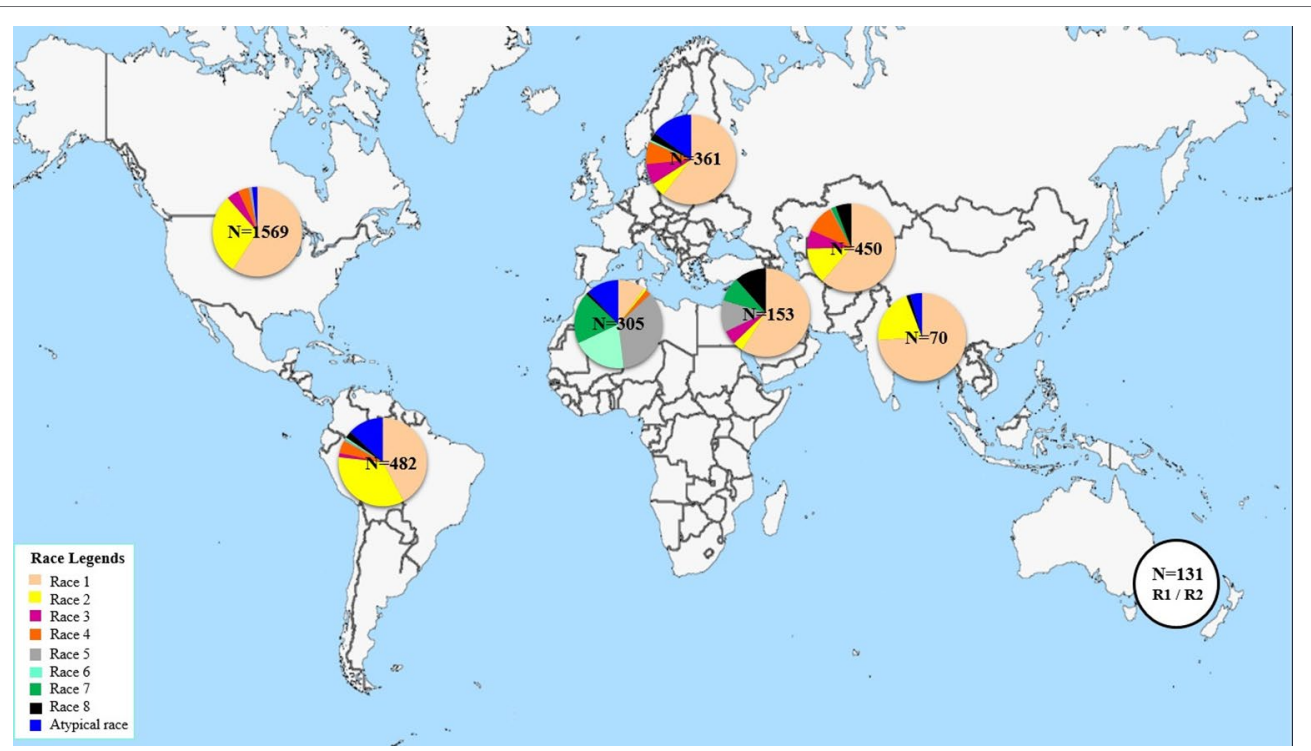

FIGURE 5 | Distribution of Ptr races across worldwide geographical regions since 1989.

isolates (races 5, 6, 7, and 8) dominating these regions, but are absent or rarely found in the rest of the world (Figure 5). Race 2 , ranks second in frequency after race 1 in the Americas, and in Asia, but it was found at low frequencies in Europe, the Caucuses, and in North Africa (Canada and USA) (Figure 5). In Australia and New Zealand, the exact identity of races 1 or 2 remains to be investigated but a combination of these two races is possible, and this concluded based on the presence of ToxA but not ToxB in the pathogen populations in these regions (Antoni et al., 2010; Weith, 2015). Races 3 and 4, do occur in various geography but at low frequencies, except when the fungus is recovered from grasses, then race 4 is the most prevalent one (Ali and Francl., 2003). There are several reports on isolates that do not fit within the known 8 races, and were denoted here as atypical (Figure 5).

North America so far is the most investigated region in the world with over 1500 isolates being characterized mainly as races 1 or 2 over the last 30 years (Figure 5). Yet, up to 5 different races were recovered from a single visit to a single field in the wheat center of origin region (Lamari et al., 2005b). Six races were identified from a small collection of only 55 isolates in Algeria (Benslimane et al., 2011). Information on Ptr race structure in western Europe is limited, likely the pathogen is not as important in that region, but few reports from eastern, eastern south, and central Europe, showed dominance of race 1 isolates, and few isolates amplified the ToxB gene (Sarova et al., 2005; LeisovaSvobodova et al., 2010; Abdullah et al., 2017b). Russian Ptr populations from Northwest and North Caucasus territory harbor all the eight races (Mironenko et al., 2019).

In this current study, four different races (races 2, 4, 5, and 7) were detected beside one atypical virulence group that did not fit under the current race system (Table 1). These atypical isolates induced the same symptoms as race 7 isolates, but lacked the ToxA gene (Table 1). Both race 7 and the atypical isolates represented $93 \%$ of the pathogen population in Tunisia, with race 7 at $49 \%$ and the atypical isolates at $44 \%$. Races 2,4 , and 5 occurred at a very low frequencies, $1 \%, 1 \%$, and $4 \%$, respectively. In terms of effectors prevalence, ToxB and its homolog, toxb, predominated the Tunisian Ptr population, and occurred at $97 \%$ and $93 \%$, respectively, while ToxA occurred in $51 \%$ of the tested isolates.

Ptr race composition in Tunisia generally was similar to the races present in regions in close proximity to the wheat center of origin, where both Ptr ToxA and Ptr ToxB-producing isolates are reported (Lamari et al., 2005b). However, unlike previous results from North Africa (Benslimane et al., 2011; Gamba et al., 2017), Ptr in Tunisia in this study lacked races 1,6 , and 8 . Yet, race 3 was never reported in previous studies in North Africa (Lamari et al., 1995; Benslimane et al., 2011; Gamba et al., 2017) or in this current study.

In Morocco, a more recent study investigated a larger collection of 135 single spore isolates, and showed the presence of races 1 , 5, 6, and 7 (Gamba et al., 2017). While races 1 and 7 dominated Algerian wheat, these races were reported at low percentage in Morocco, as races 5 and 6 were the most predominant ones, and together accounted for $91 \%$ of detected isolates. In this study, race 7 occurred at $50 \%$ which is very close to its frequency in Algeria at $40 \%$. Similar to what was reported in Morocco, our results, showed predominance of Ptr ToxB-producing isolates at $97 \%$, although the race designation varied between the two countries. Previous survey conducted in eastern Algeria in 1993, showed that Ptr isolates were grouped in either race 5 or race 6 (Lamari et al., 1995; Strelkov et al., 2002). Only in 2011, races 1 and 4 were reported from Algeria (Benslimane et al., 2011), but there is no additional survey between these two studies in Algeria to explain the differences in these results.

Although Morocco, Algeria, and Tunisia are all in North Africa and generally share similar geography and common landrace, but finding conflicting results on the diversity or composition of Ptr 
races in close by countries is not uncommon. For example, in Azerbaijan, where combinations of all effectors and most of the known races were detected (Lamari et al., 2005b), only one or two races (races 1 and 2) were found in the neighboring regions such as Uzbekistan, Kazakhstan, Kryghyztan, and Iran (Lamari et al., 2005b; Momeni et al., 2014). The conflict in results regarding race composition among these neighboring regions was in part attributed to the host from which these isolates were recovered. In Azerbaijan, local varieties and land races are often planted, where in Uzbekistan, Kazakhstan, Kryghyztan, and Iran, modern cultivars developed by the International Maize and Wheat Improvement Center (CIMMYT) and the International Center for Agricultural Research in the Dry Areas (ICARDA), are planted often rather than local varieties (Lamari et al., 2005b; Momeni et al., 2014). Genetic diversity in Ptr from a global collection, showed a significant differentiation between Ptr ToxA-producing and non-producing isolates, and suggested that host-specificity imposed by necrotrophic effectors may lead to the differentiation among races (Aboukhaddour et al., 2011), as majority of Ptr ToxA-non producers were collected from durum (Aboukhaddour et al., 2011). Indeed, the three race 5 isolates identified in this current study were collected from durum, and in the previous studies in Algeria and Morocco, all races 5 and 6 were recovered from durum only (Lamari et al., 1995; Gamba et al., 2017).

The variation among races in North Africa is hard to attribute only to geography, yet the number of fields sampled, recovered isolates, and years of survey is relatively small to draw a final conclusion. One common finding in North Africa, is the lack of race 3, a Ptr ToxC-producer, in this region, and this race however was the most frequent in Syria (Lamari et al., 2005b). In Tunisia, there was a total absence of Ptr ToxC activity that remain to be explained, yet races 6 and 8 were reported in North Africa (Lamari et al., 1995; Benslimane et al., 2011; Gamba et al., 2017) and these races produces the Ptr ToxC effector.

In this study, we report on the finding of atypical isolates occurring at a high percentage of $44 \%$ in Ptr population in Tunisia, these isolates have the ability to cause necrosis on "Glenlea" a Tsn1-carrying genotype, but lack the ToxA gene. Therefore, could not fit under the current race system describe by Lamari et al. (2003). Recently, a similar finding describing predominant necrosis on "Glenlea" by Ptr isolates that lack ToxA gene was reported in northern and western Siberian pathogen population (Mironenko et al., 2019). This indicates the widespread of additional races and necrotic factors in Ptr populations.

Ptr ToxA, so far is the only described necrotic causing effector, its gene, ToxA, has a very conserved sequence and believed to be horizontally transferred into Ptr genome from a related species $S$. nodorum (Friesen et al., 2006). ToxA sequence is highly conserved in Ptr, and only one haplotype (H14) was detected when a collection of 54 Ptr isolates from geographically diverse pathogen populations were screened (Friesen et al., 2006). Stukenbrock and McDonald (2007) reported three different haplotypes in a collection of $61 \mathrm{Ptr}$ isolates collected from different geographic regions including the $54 \mathrm{Ptr}$ isolates previously investigated by Friesen et al. (2006). These three ToxA haplotypes denoted H14(59), H15(1), and H16(1), where number in parentheses represent the number of isolates belonging to each haplotype. In another study by Aboukhaddour et al. (2013), 16 Ptr isolates collected in 2010 from Alberta, Canada were all found to have ToxA H15 (MN062685 to MN062700). In contrast to ToxA haplotypes in $S$. nodorum which has several haplotypes, only 3 ToxA haplotypes were recorded in Ptr (Stukenbrock and McDonald, 2007; McDonald et al., 2013). In this study, ToxA sequence comparative analysis showed that, all Tunisian Ptr isolates were found to have ToxA sequences identical to the previously identified ToxA haplotype 15 (H15: Figure 4). ToxA haplotyping is well studied in S. nodorum (Friesen et al., 2006; Stukenbrock and McDonald, 2007; McDonald et al., 2013), but poorly studied in Ptr and to our knowledge, this is the first Ptr ToxA genotyping analysis in Tunisia and North Africa. The ToxA haplotype in Tunisian isolates (H15) is identical to the USA isolate Pt-1C (Ciuffetti et al., 1997), and the Canadian Ptr isolates (MN062685 to MN062700).

Before this current study, 20 different ToxA haplotypes were identified, 3 in Ptr and 17 in S. nodorum (Stukenbrock and McDonald, 2007; McDonald et al., 2013). However, additional homolog sequence of ToxA in S. nodorum isolate Fr15-02 was found in the GenBank (Accession MH511823) and was submitted by The School of Molecular and Life Sciences in Western Australia, Australia. In this study, we found that this submitted sequence (Accession MH511823) does not match any of the previously identified haplotypes (Figure 4). This indicates additional haplotypes of ToxA gene. The high ToxA sequence diversity in $S$. nodorum (14 haplotypes) in comparison to the low sequence diversity in Ptr (3 haplotypes) confirmed previous conclusions on a more recent acquisition of ToxA by Ptr genome (Friesen et al., 2006; Stukenbrock and McDonald, 2007).

Unlike the conserved sequence of ToxA in Tunisian Ptr, ToxB, and its homolog toxb were both amplified in the same isolate from $93 \%$ of tested isolates, and was not detected in races 2 and 4 isolates. The Tunisian race 4 in this study did not amplify toxb, however, the primers for tox $b$ used in this study were designed based on the sequence of toxb homolog in a Canadian race 4 isolate, and variation among different toxb homologs from different regions or races may render the PCR negative. Usually, tox $b$ which encodes non-functional protein is found in isolates of races 3 and 4 , that lack the active ToxB gene (Strelkov et al., 2006), but here to find the ToxB and its homolog toxb in the same Tunisian isolates of races 5, 7, and the atypical isolates is an interesting finding reflecting on a more complex evolutionary history of ToxB and its homolog in this species.

No doubt, that the Ptr race system greatly impacted our understanding of necrotrophic effectors-host interaction and gave us the ability to differentiate among the eight races of Ptr. However, the need to expand it and identify additional effectors was discussed already by the scientists who established this system in the first place (Lamari et al., 2003). Obviously, the ability to identify the full races of a pathogen is limited by the differential set in use, and additional races, and effectors most likely exist in Ptr. In this study, the ability to cause necrosis without the presence 
of ToxA gene, can be explained by the presence of additional pathogenicity gene(s) that await further characterization.

\section{DATA AVAILABILITY STATEMENT}

All datasets generated for this study are included in the article/ Supplementary Material.

\section{AUTHOR CONTRIBUTIONS}

SK performed most of the work in this manuscript and drafted the manuscript, $\mathrm{MH}$ performed sequence analysis and helped in aspects of molecular work, TD provided considerable help in purifying and growing the cultures and assisted in all experimental aspects. MC and RA conceived the experiment and RA with $\mathrm{MH}$ revised and edited the work. All authored reviewed and contributed to the manuscript. Survey and single spore isolation was done in Tunisia and rest of the work was performed in Lethbridge Research Centre in Agriculture and Agri-Food Canada.

\section{REFERENCES}

Abdullah, S., Sehgal, S., and Ali, A. (2017a). Race diversity of Pyrenophora triticirepentis in South Dakota and response of predominant wheat cultivars to tan spot. J. Plant Pathol. Microbiol. 8, 409. doi: 10.4172/2157-7471.1000409

Abdullah, S., Sehgal, S. K., Ali, S., Liatukas, Z., Ittu, M., and Kaur, N. (2017b). Characterization of Pyrenophora tritici-repentis (Tan Spot of Wheat) races in baltic states and romania. Plant Pathol. J. 33, 133-139. doi: 10.5423/ppj. oa.10.2016.0214

Aboukhaddour, R., and Strelkov, S. E. (2016). Exploring de novo specificity: the Pyrenophora tritici-repentis-barley interaction. Plant Pathol. 65, 1347-1357. doi: $10.1111 /$ ppa. 12500

Aboukhaddour, R., Cloutier, S., Ballance, G. M., and Lamari, L. (2009). Genome characterization of Pyrenophora tritici-repentis isolates reveals high plasticity and independent chromosomal location of ToxA and ToxB. Mol. Plant Pathol. 10, 201-212. doi: 10.1111/j.1364-3703.2008.00520.x

Aboukhaddour, R., Cloutier, S., Lamari, L., and Strelkov, S. E. (2011). Simple sequence repeats and diversity of globally distributed populations of Pyrenophora tritici-repentis. Can. J. Plant Pathol. 33, 389-399. doi: 10.1080/ 07060661.2011 .590821

Aboukhaddour, R., Turkington, T. K., and Strelkov, S. E. (2013). Race structure of Pyrenophora triciti-repentis ( $\tan$ spot of wheat) in Alberta, Canada. Can. J. Plant Pathol. 35, 256-268. doi: 10.1080/07060661.2013.782470

Ali, S., and Francl, L. J. (2002). A new race of Pyrenophora tritici-repentis from Brazil. Plant Dis. 86, 1050-1050. doi: 10.1094/pdis.2002.86.91050c

Ali, S., and Francl, L. J. (2003). Population race structure of Pyrenophora triticirepentis prevalent on wheat and nonce real grasses in the great plains. Plant Dis. 87, 418-422. doi: 10.1094/pdis.2003.87.4.418

Ali, S., Francl, L. J., and De Wolf, E. D. (1999). First report of Pyrenophora triticirepentis race 5 from North America. Plant Dis. 83, 591-591. doi: 10.1094/ pdis.1999.83.6.591a

Ali, S., Francl, L. J., Iram, S., and Ahmad, I. (2001). First report of tan spot on wheat in Pakistan. Plant Dis. 85, 1031-1031. doi: 10.1094/pdis.2001.85.9.1031b

Ali, S., Gurung, S., and Adhikari, T. B. (2010). Identification and characterization of novel isolates of Pyrenophora tritici-repentis from Arkansas. Plant Dis. 94, 229-235. doi: 10.1094/pdis-94-2-0229

Altschul, S. F., Gish, W., Miller, W., Myers, E. W., and Lipman, D. J. (1990). Basic local alignment search tool. J. Mol. Biol. 215, 403-410. doi: 10.1016/ s0022-2836(05)80360-2

Andrie, R. M., and Ciuffetti, L. M. (2011). Pyrenophora bromi, causal agent of brownspot of bromegrass, expresses a gene encoding a protein with homology

\section{FUNDING}

Funding from the University of Carthage to SK, and funding from Agriculture and Agri-Food Canada and Alberta Wheat Commission and Saskatchewan Wheat Development Commission to RA. The funding bodies were not involved in the design of the experiments and collection, analysis, and interpretation of data, or in the writing of this manuscript.

\section{ACKNOWLEDGMENTS}

We thank Ryan Gourlie and Gaganpreet Kaur Dhariwal at AAFC Lethbridge for their technical assistance in this study.

\section{SUPPLEMENTARY MATERIAL}

The Supplementary Material for this article can be found online at: https://www.frontiersin.org/articles/10.3389/fpls.2019.01562/ full\#supplementary-material

and similar activity to Ptr ToxB, a host-selective toxin of wheat. Mol. Plant Microbe Interact. 24, 359-367. doi: 10.1094/mpmi-06-10-0142

Andrie, R. M., Pandelova, I., and Ciuffetti, L. M. (2007). A combination of phenotypic and genotypic characterization strengthens Pyrenophora tritici-repentis race identification. Phytopathology 97, 694-701. doi: 10.1094/PHYTO-97-6-0694

Andrie, R. M., Schoch, C. L., Hedges, R., Spatafora, J. W., and Ciuffetti, L. M. (2008). Homologs of ToxB, a host-selective toxin gene from Pyrenophora tritici-repentis, are present in the genome of sister-species Pyrenophora bromi and other members of the Ascomycota. Fungal Genet. Biol. 45, 363-377. doi: 10.1016/j.fgb.2007.10.014

Antoni, E. A., Rybak, K., Tucker, M. P., Hane, J. K., Solomon, P. S., Drenth, A., et al. (2010). Ubiquity of ToxA and absence of ToxB in Australian populations of Pyrenophora tritici-repentis. Australas. Plant Pathol. 39, 63-68. doi: 10.1071/ap09056

Ballance, G. M., Lamari, L., Kowatsch, R., and Bernier, C. C. (1996). Cloning, expression and occurrence of the gene encoding the Ptr necrosis toxin from Pyrenophora tritici-repentis. Mol. Plant Pathol. On-line Publication/1996/1209/ballance.

Benslimane, H., Lamari, L., Benbelkacem, A., Sayoud, R., and Bouznad, Z. (2011). Distribution of races of Pyrenophora tritici-repentis in Algeria and identication of a new virulence type. Phytopathol. Mediterr. 50, 203-211. doi: 10.14601/ Phytopathol_Mediterr-8746

Bertagnolli, V. V., Ferreira, R. J., Liu, Z., Rosa, C. A., and Deuner, C. (2019). Phenotypical and genotypical characterization of Pyrenophora triticirepentis races in Brazil. Eur. J. Plant Pathol. 154, 995-1007. doi: 10.1007/ s10658-019-01720-3

Ciuffetti, L. M., Tuori, R. P., and Gaventa, J. M. (1997). A single gene encodes a selective toxin causal to the development of tan spot of wheat. Plant Cell. 9, 135-144. doi: 10.1105/tpc.9.2.135

De Wolf, E. D., Effertz, R. J., Ali, S., and Francl, L. J. (1998). Vistas of tan spot research. Can. J. Plant Pathol. 20, 349-370. doi: 10.1080/07060669809500404

Dhingra, O. D., and Sinclair, J. B. (1986). Basic plant pathology methods (Boca Raton, FL: CRC Press).

Effertz, R. J., Meinhardt, S. W., Anderson, J. A., Jordahl, J. G., and Francl, L. J. (2002). Identification of a Chlorosis-Inducing Toxin from Pyrenophora triticirepentis and the chromosomal location of an insensitivity locus in wheat. Phytopathology 92, 527-533. doi: 10.1094/phyto.2002.92.5.527

Engle, J. S., Madden, L. V., and Lipps, P. E. (2006). Distribution and pathogenic characterization of Pyrenophora tritici-repentis and Stagonospora nodorum in Ohio. Phytopathology 96, 1355-1362. doi: 10.1094/phyto-96-1355

Freile, S. E. S. (2018). Characterization of tan spot fungus populations on wheat in oklahoma. [dissertation/master's thesis] (Quito, Ecuador: Universidad de las Fuerzas Armadas ESPE). 
Friesen, T. L., Ali, S., Klein, K. K., and Rasmussen, J. B. (2005). Population genetic analysis of a global collection of Pyrenophora tritici-repentis, causal agent of tan spot of wheat. Phytopathology 95, 1144-1150. doi: 10.1094/phyto-95-1144

Friesen, T. L., Stukenbrock, E. H., Liu, Z., Meinhardt, S., Ling, H., Faris, J. D., et al. (2006). Emergence of a new disease as a result of interspecific virulence gene transfer. Nat. Genet. 38, 953-956. doi: 10.1038/ng1839

Gamba, F. M., Strelkov, S. E., and Lamari, L. (2012). Virulence of Pyrenophora tritici-repentis in the Southern Cone Region of South America. Can. J. Plant Pathol. 34, 545-550. doi: 10.1080/07060661.2012.695750

Gamba, F. M., Bassi, F. M., and Finckh, M. R. (2017). Race structure of Pyrenophora tritici-repentis in Morocco. Phytopathol. Mediterr. 56, 119-126. doi: 10.14601/ Phytopathol_Mediterr-18830

Gultyaeva, E. I., Kovalenko, N. M., Shamanin, V. P., Tyunin, V. A., Shreyder, E. R., Shaidayuk, E. L., et al. (2018). Population structure of leaf pathogens of common spring wheat in the West Asian regions of Russia and North Kazakhstan in 2017. Vavilov. J. Genet. Breed. 22, 363-369. doi: 10.18699/vj18.372

Krupinsky, J. M. (1982). Observations on the host range of isolates of Pyrenophora trichostoma. Can. J. Plant Pathol. 4, 42-46. doi: 10.1080/07060668209501335

Lamari, L., and Bernier, C. C. (1989a). Evaluation of wheat lines and cultivars to tan spot [Pyrenophora Tritici-Repentis] based on Lesion type. Can. J. Plant Pathol. 11, 49-56. doi: 10.1080/07060668909501146

Lamari, L., and Bernier, C. C. (1989b). Virulence of isolates of Pyrenophora triticirepentis on 11 wheat cultivars and cytology of the differential host reactions. Can. J. Plant Pathol. 11, 284-290. doi: 10.1080/07060668909501114

Lamari, L., and Strelkov, S. E. (2010). Minireview/Minisynthèse the wheat/ Pyrenophora tritici-repentis interaction: progress towards an understanding of tan spot disease. Can. J. Plant Pathol. 32, 4-10. doi: 10.1080/07060661003594117

Lamari, L., Sayoud, R., Boulif, M., and Bernier, C. C. (1995). Identification of a new race in Pyrenophora tritici-repentis: implications for the current pathotype classification system. Can. J. Plant Pathol. 17, 312-318. doi: 10.1080/07060669509500668

Lamari, L., Gilbert, J., and Tekauz, A. (1998). Race differentiation in Pyrenophora tritici-repentis and survey of physiologic variation in western Canada. Can. J. Plant Pathol. 20, 396-400. doi: 10.1080/07060669809500410

Lamari, L., Strelkov, S. E., Yahyaoui, A., Orabi, J., and Smith, R. B. (2003). The Identification of Two New Races of Pyrenophora tritici-repentis from the host center of diversity confirms a one-to-one relationship in tan spot of wheat. Phytopathology 93, 391-396. doi: 10.1094/phyto.2003.93.4.391

Lamari, L., McCallum, B. D., and Depauw, R. M. (2005a). Forensic pathology of Canadian bread wheat: the case of tan spot. Phytopathology 95, 144-152. doi: 10.1094/phyto-95-0144

Lamari, L., Strelkov, S. E., Yahyaoui, A., Amedov, M., Saidov, M., Djunusova, M., et al. (2005b). Virulence of Pyrenophora tritici-repentis in the countries of the Silk Road. Can. J. Plant Pathol. 27, 383-388. doi: 10.1080/07060660509507236

Leisova-Svobodova, L., Hanzalova, A., and Kucera, L. (2010). Expansion and variability of the Ptr ToxA gene in populations of Pyrenophora tritici-repentis and Pyrenophora teres. J. Plant Pathol. 92, 729-735.

Lepoint, P., Renard, M.-E., Legrève, A., Duveiller, E., and Maraite, H. (2010). Genetic Diversity of the mating type and toxin production genes in Pyrenophora tritici-repentis. Phytopathology 100, 474-483. doi: 10.1094/phyto-100-5-0474

Lu, S., Gillian Turgeon, B., and Edwards, M. C. (2015). A ToxA-like protein from Cochliobolus heterostrophus induces light-dependent leaf necrosis and acts as a virulence factor with host selectivity on maize. Fungal Genet. Biol. 81, 12-24. doi: 10.1016/j.fgb.2015.05.013

MacLean, D. E., Aboukhaddour, R., Tran, V. A., Askarian, H., Strelkov, S. E., Turkington, T. K., et al. (2017). Race characterization of Pyrenophora triticirepentis and sensitivity to propiconazole and pyraclostrobin fungicides. Can. J. Plant Pathol. 39, 433-443. doi: 10.1080/07060661.2017.1387178

Maraite, H., Mercado-Vergnes, D., Renard, M.-E., Zhanarbekova, A., and Duveiller, E. (2006). Relevance of pathogen diversity in management of leaf spot and leaf blight diseases on wheat in Central Asia. Agromeridian 2, 105-114.

Martinez, J. P., Ottum, S. A., Ali, S., Francl, L. J., and Ciuffetti, L. M. (2001). Characterization of the ToxB gene from Pyrenophora tritici-repentis. Mol. Plant-Microbe Interact. 14, 675-677. doi: 10.1094/MPMI.2001.14.5.675

McDonald, M. C., Ahren, D., Simpfendorfer, S., Milgate, A., and Solomon, P. S. (2018). The discovery of the virulence gene ToxA in the wheat and barley pathogen Bipolaris sorokiniana. Mol. Plant Pathol. 19, 432-439. doi: 10.1111/mpp.12535

McDonald, M. C., Oliver, R. P., Friesen, T. L., Brunner, P. C., and McDonald, B. A. (2013). Global diversity and distribution of three necrotrophic effectors in
Phaeosphaeria nodorum and related species. New Phytologist 199, 241-251. doi: $10.1111 / \mathrm{nph} .12257$

Mironenko, N., Kovalenko, N. M., and Baranova, O. (2019). Characteristics of the geographically distant populations of Pyrenophora tritici-repentis in terms of virulence and ToxA and ToxB toxin-forming genes. Plant Prot. News 1, 24-29. doi: 10.31993/2308-6459-2019-1(99)-24-29

Momeni, H., Aboukhaddour, R., Javan-Nikkhah, M., Razavi, M., Nagha, M. R., Akhavan, A., et al. (2014). Race identification of Pyrenophora tritici-repentis in Iran. J. Plant Pathol. 96, 287-294. doi: 10.4454/JPP.V96I2.036

Moreno, M. V., Stenglein, S., and Perelló, A. E. (2015). Distribution of races and Tox genes in Pyrenophora tritici-repentis isolates from wheat in Argentina. Trop. Plant Pathol. 40, 141-146. doi: 10.1007/s40858-015-0011-2

Morrall, R. A. A., and Howard, R. J. (1975). The epidemiology of leaf spot disease in a native prairie. II. Airborne spore populations of Pyrenophora triticirepentis. Can. J. Bot. 53, 2345-2353. doi: 10.1139/b75-260

Nicholas, K. B., Nicholas, H. B., and Deerfield, D. W. (1997). GeneDoc: analysis and visualization of genetic variation. Embnew. News 4, 14.

Rozen, S., and Skaletsky, H. (2000). Primer 3 on for general users and for biological programmers. Methods In Mol. Biol. 132, 365-386. doi: 10.1385/1-59259-192-2:365

Santana, F. M., Clebsch, C. C., and Friesen, T. L. (2008). Data from: caracterização de raças de Pyrenophora tritici-repentis, agente etiológico da mancha amarela do trigo, no sul do Brasil. Boletim. Pesquisa. e. Desenvolv. Online 60.

Sarova, J., Hanzalova, A., and Bartos, P. (2005). Races of Pyrenophora tritici-repentis in the Czech Republic. Acta Agrobotanica. 58, 73-78. doi: 10.5586/aa.2005.011

See, P. T., Iagallo, E. M., Oliver, R. P., and Moffat, C. S. (2019). Heterologous expression of the Pyrenophora tritici-repentis effector proteins ToxA and ToxB, and the prevalence of effector sensitivity in Australian cereal crops. Front. In Microbiol.: 10. doi: 10.3389/fmicb.2019.00182

Shaukat, A., and Francl, L. J. (2002). Race structure of Pyrenophora tritici-repentis isolates obtained from wheat in south america. Plant Prot. Sci. 38, 302-304. doi: 10.17221/10473-pps

Singh, P. K., Mergoum, M., and Hughes, G. R. (2007). Variation in virulence to wheat in Pyrenophora tritici-repentis population from Saskatchewan, Canada, from 2000 to 2002. Can. J. Plant Pathol. 29, 166-171. doi: 10.1080/ 07060660709507453

Strelkov, S. E., Lamari, L., and Ballance, G. M. (1999). Characterization of a hostspecific protein toxin (Ptr ToxB) from Pyrenophora tritici-repentis. Mol. PlantMicrobe Interact. 12, 728-732. doi: 10.1094/mpmi.1999.12.8.728

Strelkov, S. E., Lamari, L., Sayoud, R., and Smith, R. B. (2002). Comparative virulence of chlorosis-inducing races of Pyrenophora tritici-repentis. Can. J. Plant Pathol. 24, 29-35. doi: 10.1080/07060660109506967

Strelkov, S. E., Kowatsch, R. F., Ballance, G. M., and Lamari, L. (2006). Characterization of the ToxB gene from North African and Canadian isolates of Pyrenophora tritici-repentis. Physiol. Mol. Plant Pathol. 67, 164-170. doi: 10.1016/j.pmpp.2005.12.004

Stukenbrock, E. H., and McDonald, B. A. (2007). Geographical variation and positive diversifying selection in the host-specific toxin SnToxA. Mol. Plant Pathol. 8, 321-332. doi: 10.1111/j.1364-3703.2007.00396.x

Summerell, B. A., and Burgess, L. W. (1988). Saprophytic colonization of wheat and barley by Pyrenophora tritici-repentis in the field. Trans. Br. Mycol. Soc. 90, 551-556. doi: 10.1016/S0007-1536(88)80058-5

Thompson, J. D., Gibson, T. J., Plewniak, F., Jeanmougin, F., and Higgins, D. G. (1997). The CLUSTAL_X windows interface: flexible strategies for multiple sequence alignment aided by quality analysis tools. Nucleic Acids Res. 25, 4876-4882. doi: 10.1093/nar/25.24.4876

Weith, S. (2015) (New Zealand). Pyrenophora tritici-repentis the causal agent of tan spot: Characterisation of New Zealand populations. [dissertation/master's thesis].

Conflict of Interest: The authors declare that the research was conducted in the absence of any commercial or financial relationships that could be construed as a potential conflict of interest.

Copyright (c) 2019 Kamel, Cherif, Hafez, Despins and Aboukhaddour. This is an openaccess article distributed under the terms of the Creative Commons Attribution License (CC BY). The use, distribution or reproduction in other forums is permitted, provided the original author(s) and the copyright owner(s) are credited and that the original publication in this journal is cited, in accordance with accepted academic practice. No use, distribution or reproduction is permitted which does not comply with these terms. 